Journal of Animal and Veterinary Advances 9 (21): 2691-2694, 2010

ISSN: $1680-5593$

(C) Medwell Journals, 2010

\title{
Ruminal and Post-Ruminal Protein Disappearance of Chemically Treated Alfalfa Silage and the Effect of the Silage Containing Diets on Performance of Holstien Lactating Dairy Cows
}

\author{
M. Danesh Mesgaran, A. Vakili and J. Tavallaei \\ Department of Animal Science, Faculty of Agriculture, Ferdowsi University of Mashhad, \\ P.O. Box, 91775-1163, Mashhad, Iran
}

\begin{abstract}
Alfalfa hay (30\% dry matter) was ensiled as untreated (AS) or treated with formic acid (ASF, $24 \mathrm{~mL} \mathrm{~kg}^{-1} \mathrm{DM}$ ) or formic acid+urea (ASFU, $24 \mathrm{~mL}$ and $4 \mathrm{~g} \mathrm{~kg}^{-1} \mathrm{DM}$, respectively). Disappearance of protein and dry matter from the samples was determined using the in situ mobile bag procedure. In lactation trail, 12 Holstein cows received diets containing $28.5 \%$ AS or ASF or ASFU, $30 \%$ corn silage, $7 \%$ alfalfa hay and $34.5 \%$ concentrate for 8 weeks. The chemically processed applied caused a significant decrease in ruminal and an increase in post-ruminal dry matter disappearances of the silages evaluated $(\mathrm{p}<0.05)$. Dry matter intake and yields of milk did not influenced by the experimental diets. Milk urea nitrogen concentration of the cows received the diet containing ASFU were significantly lower than the others $(\mathrm{p}<0.05)$. Blood plasma concentration of glucose was increased when the diet containing of ASF was fed to the animals $(\mathrm{p}<0.05)$ compared with the others.
\end{abstract}

Key words: Alfalfa silage, formic acid, urea, degradability, ASFU, glucose

\section{INTRODUCTION}

Alfalfa protein is subject to extensive degradation during ensiling as much as $75-87 \%$ of the total nitrogen present in alfalfa silage may be non-protein nitrogen (Muck, 1987). This resulted in inefficient $N$ use especially in diets in which fermentable energy is limiting. Formic acid commonly is used as a preservative for direct-cut silage in northern Europe. Formic acid-treated alfalfa hay silage had lower $\mathrm{pH}$ and $\mathrm{NH} 3$ concentrations than untreated controls and higher water-insoluble $\mathrm{N}$ compared with the intact silage (Barry et al., 1978; Lancaster and Brunswick, 1977).

Formic acid was more consistent than bacterial inoculants in reducing protein degradation and deamination in clover silage (Woolford and Sawczyc, 1984). In contrast to enzymes and inoculants that stimulate silage fermentation, formic acid restricts fermentation and decreases silage $\mathrm{pH}$ by direct acidification (Muck and Kung, 1997; Nagel and Broderick, 1992; Waldo et al., 1971). Therefore, formic acid is commonly used in crops with low DM and sugar concentrations. Under these conditions, it is especially important to decrease $\mathrm{pH}$ rapidly $(<4.2)$ to prevent clostridial growth (McDonald et al., 1991; Muck and Kung, 1997). Well fermented, highly digestible silages containing high concentration of lactic acid and low acetic acid, ammonia- $\mathrm{N}$ and cell wall concentrations are associated with higher intake and improved animal performance (Wilkins et al., 1971). Increased dry matter intake and $\mathrm{N}$ retention have been reported in sheep (Barry et al., 1978) and dairy heifers (Waldo et al., 1971) fed treated alfalfa silage. Little information is available on milk production when formic acid-treated alfalfa silage is fed to dairy cattle. Glenn et al. (1986) reported a trend for higher milk yields when cows were fed alfalfa silage treated with formic acid plus formaldehyde however, alfalfa comprised only $30 \%$ of the diet DM. The objective of this study was to test the effect of treating alfalfa silage with formic acid and urea on in situ mobile bag DM and protein disappearances and the effect of diets containing the silages on dry matter intake, milk and milk component yields and blood plasma metabolite concentrations of Holstein lactating dairy cattle.

\section{MATERIALS AND METHODS}

Ensiling and chemical analysis: Freshly chopped alfalfa hay at second cutting that was prepared with a commercial forage harvester and contained 30\% dry matter was used in this experiment. Alfalfa hay was ensiled as untreated (AS) or chemically treated using

Corresponding Author: A. Vakili, Department of Animal Science, Faculty of Agriculture, Ferdowsi University of Mashhad, P.O. Box, 91775-1163, Mashhad, Iran 
formic acid (ASF, $24 \mathrm{~mL} \mathrm{~kg}^{-1} \mathrm{DM}$ ) or formic acid+urea (ASFU, $24 \mathrm{~mL}$ and $4 \mathrm{~g} \mathrm{~kg}^{-1} \mathrm{DM}$, respectively) for 40 days. Formic acid was carried and used under the safety protocol of Ferdowsi University of Mashad using special instruments.

The acid (95\%) was diluted with water (acid:water 1:4, $\mathrm{vol} / \mathrm{vol}$ ) and stored in an artificial plastic container until it was mixed with the forage. Dry matter, organic matter, silage $\mathrm{pH}$ and Chemical composition including Crude Protein (CP), Non-Protein Nitrogen (NPN) and ammonia-N concentrations were determined using standard methods (AOAC, 1990).

Mobile nylon bag technique: Ruminal and post-ruminal disappearance of protein and DM from the silage samples were determined using the in situ mobile bag procedure as described by Danesh and Stern (2005). Two Holstein steers ( $450 \pm 20 \mathrm{~kg}$ Body weight) fitted with ruminal fistulae and T-shaped intestinal cannulae were used. Animals were fed $5.1 \mathrm{~kg}$ of DM of alfalfa hay, $3.2 \mathrm{~kg}$ of DM corn silage and $2.5 \mathrm{~kg}$ of DM concentrate $\left(170 \mathrm{~g} \mathrm{CP} \mathrm{kg}^{-1}\right.$ of DM) per head per day, two times per day at 8.00 and $18.00 \mathrm{~h}$.

Dried silage samples were ground to pass a $2 \mathrm{~mm}$ screen. Approximately $5 \mathrm{~g}$ DM of each sample were placed into a polyester bag $(17 \times 12 \mathrm{~cm}$ with pore size of $48 \mu \mathrm{m})$ and incubated in the rumen for $12 \mathrm{~h}(8 \mathrm{bags}$ per each sample). After removal from the rumen, bags were hand washed with tap water and subsequently dried using an aired oven $\left(60^{\circ} \mathrm{C}, 48 \mathrm{~h}\right)$.

Aproximately $1 \mathrm{~g}$ of rumen-incubated residual of each bag was tranfered into a polyester mobile bag $(3 \times 6 \mathrm{~cm}$, pore size of $48 \mu \mathrm{m}$ ). Then the mobile bags were inserted into the small intestine via the intestinal cannulae at the rate of one bag every $30 \mathrm{~min}$. Removal bags from the voided faces were collected and rinsed in tap water. The bags were dried using an aired oven $\left(60^{\circ} \mathrm{C}, 48 \mathrm{~h}\right)$ and weighed to determine DM disappearance. Nitrogen concentration of un-incubated, rumen and post-rumen incubated samples was determined by the kjeldahl method (Kjeltec 2300 Auto analyzer, Foss Tecator AB, Hoganas, Sweden).

Lactation trail: Twelve early lactating Holstein dairy cows ( $50 \pm 16$ DIM, $33 \pm 4.5 \mathrm{~kg} /$ milk yield per day) were used in three groups ( 4 head per group) in a complete random design for 8 weeks.

The animals were fed with same ration in the 1 st week and the milk production data were used as covariate for the experimental data. The cows were fed the experimental diets containing 28.5\% AS OR ASF ASFU, 30\% corn silage, $7 \%$ alfalfa hay and $34.5 \%$ concentrate $(13.5 \%$ corn,
$42 \%$ barley, $12.9 \%$ soybean meal, $10.9 \%$ sugar beet pulp, $12.9 \%$ wheat bran, $5.8 \%$ cottonseed meal, $0.55 \% \mathrm{CaCo}_{3}$, $1 \%$ mineral and vitamin premix, $0.45 \%$ salt), two times per day. Feed intake and milk production were recorded daily. The samples of milk were prepared at the end of each week of the experimental period.

Blood samples were taken at the end of the last week of the experiment at $4 \mathrm{~h}$ after the morning feeding. Milk protein and milk urea- $\mathrm{N}$ concentrations were determined using the standard procedures (AOAC, 1990). Plasma from the blood samples were isolated using centrifuge at 4000 RPM per min for $10 \mathrm{~min}$. Plasma glucose and urea-N concentrations were determined as described by Nasri et al. (2007).

Statistical analysis: Data of silage chemical composition, silage $\mathrm{pH}$, ruminal and postruminal disappearance of DM and CP of the silages and plasma metabolites of the cows were analyzed according to a statistical model of $\mathrm{y}=$ overall mean + treatment effect + residual.

Data of milk yield and milk composition and dry matter intake obtained during lactation trial were analyzed as repeated in time using PROMIX of SAS (1999) according to a model of $\mathrm{y}=$ overall mean + treatment + time + treatment $\times$ time + residual. Duncan's multiple comparison test was used to determine the the significant different among the means at $\mathrm{p}<0.05$.

\section{RESULTS AND DISCUSSION}

Chemical compositions and $\mathrm{pH}\left(\mathrm{g} \mathrm{kg}^{-1}\right.$ of DM) of the alfalfa silages are shown in Table 1. Formic acid and urea caused to reduce $\mathrm{pH}, \mathrm{NH}_{3}-\mathrm{N}$ and NPN and increased $\mathrm{CP}$ and DM $(\mathrm{p}<0.05)$. Formic acid may reduce proteolysis during ensiling by either reduction of $\mathrm{pH}$ or by providing additional substrate to enhance the reduction of $\mathrm{pH}$. In addition, acid treatment of AS caused to a decrease in soluble $\mathrm{N}$ and resulted in lower ruminal degradation of the silage CP.

Lower NPN and $\mathrm{NH}_{3}-\mathrm{N}$ in alfalfa silage treated with urea and formic acid AS indicated that the $\mathrm{pH}$ drop was sufficiently more rapid, resulting in less protein being degraded in the AS treated with urea and formic acid (Behgar et al., 2008; Agbossamey et al., 1998).

Reducing silage NPN will improve utilization of CP in lactating dairy cows (Nagel and Broderick, 1992; Makonia et al., 1997). Data obtained by Nadeau et al. (1996) has shown no effects of formic acid on cell-wall concentration. Alfalfa insoluble $\mathrm{N}$ was greater for the treated silages compared with the untreated silage which indicates less proteolysis occurred during 
Table 1: Chemical composition $\left(\mathrm{g} \mathrm{kg}^{-1}\right)$ of alfalfa silage treated with urea and formic acid Alfalfa silages ${ }^{2,3,45}$

\begin{tabular}{|c|c|c|c|c|c|}
\hline \multirow[b]{2}{*}{ Chemical factor ${ }^{1}$} & & & & \multirow[b]{2}{*}{$\mathrm{SEM}^{5}$} & \multirow[b]{2}{*}{$p$-value } \\
\hline & AS & ASF & ASFU & & \\
\hline $\mathrm{pH}$ & 4.780 & 3.750 & 3.930 & 0.385 & 0.212 \\
\hline DM & 292.410 & 349.720 & 395.330 & 34.180 & 0.038 \\
\hline $\mathrm{OM}$ & 925.510 & 908.320 & 899.940 & 9.030 & 0.785 \\
\hline $\mathrm{CP}$ & 177.000 & 168.550 & 196.200 & 11.700 & 0.177 \\
\hline NPN & 17.950 & 15.950 & 14.750 & 1.040 & 0.353 \\
\hline NPN/total N & 0.630 & 0.590 & 0.470 & 0.058 & 0.635 \\
\hline${\mathrm{N}-\mathrm{NH}_{3}}$ & 0.131 & 0.998 & 0.937 & 0.170 & 0.194 \\
\hline
\end{tabular}

${ }^{1} \mathrm{DM}=$ Dry Matter, $\mathrm{OM}=$ Organic Matter, $\mathrm{CP}=$ Crude Protein, $\mathrm{NPN}=$ Non Protein Nitrogen, ${ }^{2} \mathrm{AS}=$ Untreated Alfalfa Silage, $\mathrm{ASF}=\mathrm{Alfalfa}$ Silage Treated with $24 \mathrm{~mL}$ formic acid kg${ }^{-1} \mathrm{DM}$, ASFU = Alfalfa Silage reated with $24 \mathrm{~mL}$ Formic acid and $4 \mathrm{~g} \mathrm{Urea} \mathrm{kg}{ }^{-1} \mathrm{DM},{ }^{3}$ when the difference between means is greater than two times the SEM, it is considered as signific ant $(\mathrm{p}<0.05)$, ${ }^{4}$ values were reported as the mean of 6 sampling, ${ }^{5} \mathrm{SEM}=$ Standard Error of Mean

Table 2: Ruminal and post-ruminal dry matter and protein disappearance $\left(\mathrm{g} \mathrm{kg}^{-1}\right)$ of Alfalfa silage treated with urea and formic acid using in situ mobile bag technique

\begin{tabular}{|c|c|c|c|c|c|c|}
\hline \multirow[b]{2}{*}{ Items } & \multirow[b]{2}{*}{ Factors } & \multicolumn{3}{|c|}{ Alfalfa silages $^{1}$} & \multirow[b]{2}{*}{$\mathrm{SEM}^{2}$} & \multirow[b]{2}{*}{$\mathrm{p}$-value } \\
\hline & & AS & ASF & ASFU & & \\
\hline \multirow[t]{2}{*}{ Ruminal disappearance } & $\mathrm{DM}$ & $536^{\mathrm{a}}$ & $512^{b}$ & $524^{a}$ & 9.30 & 0.01 \\
\hline & $\mathrm{CP}$ & 767 & 767 & 763 & 23.20 & 0.93 \\
\hline \multirow[t]{2}{*}{ Post-ruminal disappearance } & DM & $432^{\mathrm{a}}$ & $482^{b}$ & $472^{b}$ & 6.20 & 0.01 \\
\hline & $\mathrm{CP}$ & 868 & 881 & 875 & 6.50 & 0.80 \\
\hline
\end{tabular}

${ }_{\mathrm{A}, \mathrm{b}}$ :In each row, difference between means with different letter were significant $(\mathrm{p}<0.05),{ }^{1} \mathrm{AS}=$ Untreated Alfalfa Silage, ASF $=$ Alfalfa Silage treated with $24 \mathrm{~mL}$ Formic acid kg${ }^{-1} \mathrm{DM}, \mathrm{ASFU}=$ Alfalfa Silage treated with $24 \mathrm{~mL}$ Formic Acid and $4 \mathrm{~g} \mathrm{Urea} \mathrm{kg}^{-1} \mathrm{DM},{ }^{2} \mathrm{SEM}=\mathrm{Standard} \mathrm{Error} \mathrm{of} \mathrm{Mean}$

Table 3: Dry matter intake, milk yield, milk composition and blood metabolites of lactating cows fed diets containing LS treated with urea and formic acid Experimental diets containing alfalfa silage

\begin{tabular}{|c|c|c|c|c|c|}
\hline \multirow[b]{2}{*}{ Items } & & \multirow[b]{2}{*}{$\mathrm{SEM}^{2}$} & \multirow[b]{2}{*}{$\mathrm{p}$-value } \\
\hline & AS & $\mathrm{ASF}$ & ASFU & & \\
\hline DMI (kg day $\left.{ }^{-1}\right)$ & 23.2 & 23.1 & 22.8 & 0.242 & 0.6937 \\
\hline Milk (kg day $\left.{ }^{-1}\right)$ & 32.8 & 31.6 & 30.9 & 0.930 & 0.8383 \\
\hline Milk protein $\left(\mathrm{g} \mathrm{kg}^{-1}\right)$ & 33.1 & 32.1 & 33.6 & 0.240 & 0.2419 \\
\hline Milk urea Nitrogen $\left(\mathrm{g} \mathrm{kg}^{-1}\right)$ & $18.8^{\mathrm{a}}$ & $16.5^{\mathrm{a}}$ & $14.7^{\circ}$ & 2.070 & 0.0021 \\
\hline Milk dry matter $\left(\mathrm{g} \mathrm{kg}^{-1}\right)$ & $109.2^{\mathrm{a}}$ & $101.2^{b}$ & $114.6^{\mathrm{a}}$ & 2.420 & 0.0174 \\
\hline Plasma glucose (mg dL $\left.{ }^{-1}\right)$ & 61.9 & 56.6 & 61.3 & 2.920 & 0.4430 \\
\hline Plasma urea nitrogen $\left(\mathrm{mg} \mathrm{dL}^{-1}\right)$ & 19.6 & 17.6 & 19.7 & 1.160 & 0.1985 \\
\hline
\end{tabular}

ensiling (Ohshima and McDonald, 1977). The formic acid treated silages had lower energy, cellulose, lignin and protein but higher sugar concentrations than the untreated silages. In addition, the silages that were treated with formic acid had lower $\mathrm{pH}(\mathrm{p}<0.001)$, lactic acid, acetic acid, butyric acid, total acids and ammonia nitrogen than the untreated silages (Derbyshire et al., 1976).

Ruminal and post-ruminal dry matter and protein disappearance of the alfalfa silages are shown in Table 2. The ruminal dry matter disappearance was lower in the silages treated with formic acid and urea than the untreated silage but the post-ruminal dry matter disappearance in the control silage was lower than the other silages. Ruminal and post-ruminal protein disappearance in all silages were similar. Nadeau et al. (1996) reported greater total DM and NDF disappearances during early ruminal fermentation in situ in cellulase plus formic acid treated orchard grass and alfalfa silages compared with the control silage but the differences between treatments became smaller as the fermentation proceeded up to $96 \mathrm{~h}$ of incubation. Results of dry matter intake, milk yield and milk composition and plasma blood metabolites are shown in Table 3. Milk yield and milk protein were not significantly affected by the treatments
( $>0.05$ ). Experimental diets had a significant effect on milk urea nitrogen concentration and milk dry matter $(\mathrm{p}<0.05)$. Lower concentrations of milk urea nitrogen in cows fed the diet containing ASF might be reflecting of a difference in CP component intake (Broderick and Clayton, 1997). Blood glucose and urea nitrogen were all similar among the diets at each sampling time $(\mathrm{p}>0.05)$. However, blood glucose was numerically higher in animals fed the treated silage compared with those were fed the control silage.

\section{CONCLUSION}

In conclusion, results of the of present study demonstrate that formic acid treatment of the alfalfa silage is effective procedure in reducing $\mathrm{N}$ degradation in the silo and in the rumen and has not negative effect on milk production. In addition, the formic acid treated silage resulted in a significant shift in the disappearance site of dry matter and $\mathrm{CP}$ as post-ruminal digestion was greater in the chemically treated AS compared with the untreated. However, additional research must be done to develop an accurate on-farm test to predict when formic acid application is appropriate and what application rate is optimal. 


\section{REFERENCES}

AOAC, 1990. Official Methods of Analysis. 15th Edn., Association of Official Analytical Chemists, Arlington, VA.

Agbossamey, Y.R., P. Savoie and J.R. Seoane, 1998. Effect of maceration on nitrogen fractions in hay and silage. Can. J. Anim. Sci., 78: 399-405.

Barry, T N., J.E. Cook and R.1. Wilkins, 1978. The influence of formic acid and formal dehyde additives and type of harvesting machine on the utilization of nitrogen in alfalfa silages. 1 . The voluntary intake and nitrogen retention of young sheep consuming the silages with and without intra peritoneal supplements of DL methionine. J. Agric. Sci. (Camb.), 91: 701-701.

Behgar, M., M.D. Mesgaran, H.N. Moghadam and S. Sobhanirad, 2008. Chemical and digestibility characteristics of alfalfa silage treated with formic and/or sulphuric acid and its effect on production characteristics of early lactating cows. J. Sci. Technol. Agric. Nat. Res., 40: 340-350.

Broderick, G.A. and M.K. Clayton, 1997. A statistical evaluation of animal and nutritional factors influencing concentrations of milk urea nitrogen. J. Dairy Sci., 80: 2964-2971.

Danesh, M.M. and M.D. Stern, 2005. Ruminal and postruminal protein disappearance of various feeds originating from iranian plant varieties determined by the in situ mobile bag technique and alternative methods. Anim. Feed Sci. Technol., 118: 31-46.

Derbyshire, J.C., D.R. Waldo and C.H. Gordon, 1976. Performance of dairy cattle on wilted formic acid silages. J. Dairy Sci., 59: 1278-1285.

Glenn, B.P., H.F. Tyrrell, D.R. Waldo and H.K. Goerbg, 1986. Effects of diet nitrogen and forage nitrogen insolubility on performance of cows in early lactation. J. Dairy Sci., 69: 2825-2836.

Lancaster, R.J. and L.FC. Brunswick, 1977. Optimum rate of application of formic acid during ensiling of un wilted alfalfa. N.Z. J. Agric. Res., 20: 151-151.

Makonia, N.F.,G.A. Broderick and R.E. Mucka, 1997. Effect of modified atmospheres on proteolysis and fermentation of ensiled alfalfa. J. Dairy Sci., 80: $912-920$.
McDonald, P., A.R. Henderson and S.J.E. Heron, 1991. The Biochemistry of Silage. 2nd Edn., Chalcombe Publication, Marlow, Bucks, England.

Muck, R.E. and L.Jr. Kung, 1997. Effects of silage additives on ensiling. Proceedings of the National Silage Production Conference (NSPC'97), NRAES-99, Hershey, PA., Northeast Reg. Agric. Ext. Serv., Ithaca, NY., pp: 187-199.

Muck, R.E., 1987. Dry matter level effects on alfalfa silage quality. 1. Nitrogen transformations. Trans. Am. Soc. Agric. Eng., 30: 7-14.

Nadeau, E.M., D.R. Buxton, E. Lindgren and P. Lingvall, 1996. Kinetics of cell-wall digestion of orchardgrass and alfalfa silages treated with cellulase and formic acid. J. Dairy Sci., 79: 2207-2216.

Nagel, S.A. and G.A. Broderick, 1992. Effect of formic acid or formaldehyde treatment of alfalfa silage on nutrient utilization by dairy cows. J. Dairy Sci., 75: 140-154.

Nasri, M.H.F, M.D. Mesgaran, A. Nikkhah, R. Valizadeh, E. Kebreab and J. France, 2007. Effect of raw or roasted whole soybeans on early lactational performance and ruminal and blood metabolites in Iranian cows. J. Agric. Sci., 145: 529-537.

Ohshima, M. and P. McDonald, 1977. A review of the changes in nitrogenous compounds of herbage during ensiling. J. Sci. Food Agric., 29: 497-505.

SAS, 1999. SAS/STAT User's Guide. Version 8.2, SAS Institute, Inc., Cary, NC, USA.

Waldo, D.R., J.E. Jr. Keys, L.W. Smith and C.H. Gordon, 1971. Effecet of formic acid on recovery, intake, digestibility and growth from on unwilted silage. J. Dairy Sci., 54: 77-84.

Wilkins, R.J., K.J. Hutchinson, R.F. Wilson and C.E. Harris, 1971. The voluntary intake of silage by sheep. I. Interrelationships between silage composition and intake. J. Agric. Sci. (Camb.), 77: 531-537.

Woolford, M.K. and M.K. Sawczyc, 1984. An investigation into the effect of cultures of lactic acid bacteria on fermentation in silage. 2. Use of selected strains in laboratory scale silages. Grass Forage Sci., 39: 149-158. 